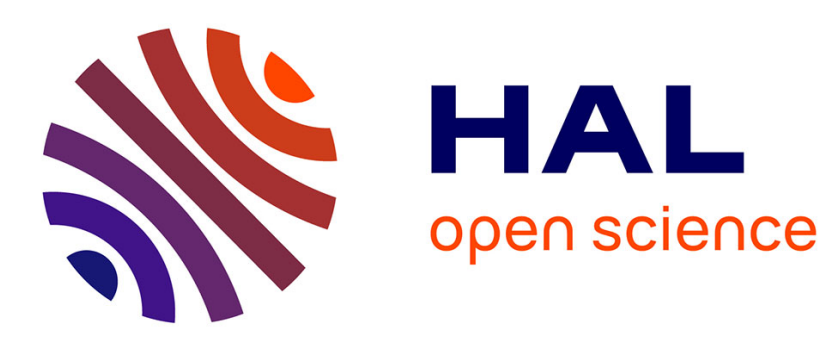

\title{
Insulating Liquids, an Alternative to Silicone Gel for Power Electronic Devices
}

\author{
Ouassim Agri, Jean-Louis Augé, Eric Vagnon, François Buret
}

\section{To cite this version:}

Ouassim Agri, Jean-Louis Augé, Eric Vagnon, François Buret. Insulating Liquids, an Alternative to Silicone Gel for Power Electronic Devices. 2019 IEEE Electrical Insulation Conference (EIC), Jun 2019, Calgary, Canada. pp.299-303, 10.1109/EIC43217.2019.9046577 . hal-02532739v1

\section{HAL Id: hal-02532739 \\ https://hal.science/hal-02532739v1}

Submitted on 6 Apr 2020 (v1), last revised 8 Apr 2020 (v2)

HAL is a multi-disciplinary open access archive for the deposit and dissemination of scientific research documents, whether they are published or not. The documents may come from teaching and research institutions in France or abroad, or from public or private research centers.
L'archive ouverte pluridisciplinaire HAL, est destinée au dépôt et à la diffusion de documents scientifiques de niveau recherche, publiés ou non, émanant des établissements d'enseignement et de recherche français ou étrangers, des laboratoires publics ou privés. 


\section{Insulating Liquids, an Alternative to Silicone Gel for Power Electronic Devices}

\author{
Ouassim AGRI \\ Ampère laboratory \\ École Centrale de Lyon \\ 69130 Ecully, France \\ ouassim.agri@ec-lyon.fr
}

\author{
Jean Louis AUGE \\ Ampère laboratory \\ Université Claude Bernard Lyon 1, \\ 69100 Villeurbanne, France \\ jean-louis.auge@univ-lyon1.fr
}

\author{
Eric VAGNON \\ Ampère laboratory \\ École Centrale de Lyon \\ 69130 Ecully, France \\ eric.vagnon@ec-lyon.fr
}

\author{
François BURET \\ Ampère laboratory \\ École Centrale de Lyon \\ 69130 Ecully, France \\ francois.buret@ec-lyon.fr
}

\begin{abstract}
This paper studies the breakdown voltage for different insulating materials encapsulating power electronic devices. A comparison between some liquids and silicone gel is carried out. The $50 \mathrm{~Hz}$ AC voltage tests were performed according to the IEC 60156 specifications. The same process was applied to the DC voltage tests due to a lack of standard procedure concerning DC voltage tests on liquids. In each case, a ceramic substrate was placed in a container filled with the insulating material. A voltage was applied between two electrodes glued on the substrate. Mineral, both synthetic and natural ester oils and silicone gel were tested. The voltages of breakdown between oils were quite similar in $\mathrm{AC}$ and $\mathrm{DC}$. The gel is more resistant to $\mathrm{DC}$ stress even though its self-healing is less than the liquids investigated.
\end{abstract}

Keywords- Insulation, liquid, power electronic device, breakdown voltage.

\section{INTRODUCTION}

Today, the energy industry faces the challenge of transporting electricity over long distances in higher voltage, in order to make use of off-shore sources and make more flexible the management of energy exchanges between countries with less losses. The increase in the voltage carried in the HVDC network makes it necessary to resize the conversion stations and therefore the power modules. This leads to higher requirements in terms of electrical insulation and operating temperature. To realize the next generation of HVDC power converters, insulating liquids seems to be a good lead [1]. Moreover, such liquids would be interesting to evacuate calories from the power device to cold areas as it is shown in power transformers [2][3]. Inside the power module, the insulating material which cover the chips and separate the power terminals is called encapsulant. It is usually made of silicone gel Fig. 1. In particular, it allows the increasing of the dielectric strength around the die and between the electrical terminals. In some cases, it must also operate at high temperatures depending on the die used ( $\mathrm{Si}, \mathrm{SiC}, \mathrm{GAN})$.

Publications have shown the possibility of using liquid dielectrics as encapsulation for power modules. In 1992 Mudawar [4] used a liquid as a direct immersion cooler. In 2012 Vladimirova [5] presented a switching cell with integrated cooler using a liquid dielectric. In 2017 Boetler [6] proposed a diode power module $\mathrm{SiC} 2 \times 15 \mathrm{kV}$ with a liquid as cooler. These works were more focused on the cooling than on the insulation.

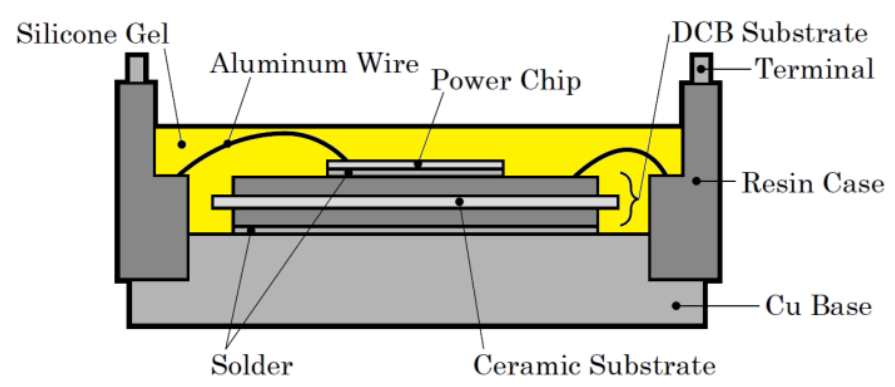

Fig. 1. Cross-section of a traditional wire-bonded power module [7].

In this paper, $\mathrm{AC}$ and $\mathrm{DC}$ breakdown voltage measurement results are presented. These measurements were done on single substrates (not in a real module), where several liquids dielectrics are used as encapsulants (mineral oil, and both synthetic and vegetable ester oils). Results are compared with those obtained with silicone gel.

\section{EXPERIMENTAL TECHNIQUES}

\section{A. Encapsulants Preparation}

\section{1) Oil Conditioning}

Before each tests, oils have undergone a specific treatment in order to reach the datasheet values, especially for the VBR (voltage breakdown) and the water content specifications. The preliminary and systematic conditioning of the oil are listed as below:

○ Vacuum filtration with a sintered glass filter (pores $10-$ $16 \mu \mathrm{m})$

- Water content measurement just after filtration

○ Breakdown voltage tests according to IEC 60156 standard [8], in order to compare with the datasheet values.

\section{2) Gel Preparation}

After the mixture of the two-part gel and filling of the test sample cell, 8 hours degassing with a vacuum pump is carried out. Then, a polymerization operation is made under $65^{\circ} \mathrm{C}$ for 4 hours.

\section{3) Datasheet and Measured Properties}

TABLE I. gives some properties linked to our study coming from the datasheets. We performed two treatments before the tests. One for AC samples and the other one for DC samples. 
Measurements after treatment are also given for the VBR and the water content in oils. Water content measurements of ester oils are higher than the typical datasheet values. However, the VBR are confident with the expected values.

TABLE I. PHYSICAL AND ELECTRICAL PROPERTIES OF THE ENCAPSULANTS FROM DATASHEET AND OUR MEASURED VALUES

\begin{tabular}{|c|c|c|c|c|c|}
\hline & Standard & $\begin{array}{c}\text { Synthetic } \\
\text { ester }\end{array}$ & $\begin{array}{c}\text { Natural } \\
\text { ester }\end{array}$ & $\begin{array}{c}\text { Mineral } \\
\text { oil }\end{array}$ & $\begin{array}{c}\text { Silicone } \\
\text { gel }\end{array}$ \\
\hline $\begin{array}{l}\text { Dielectric } \\
\text { constant }\end{array}$ & & 3.2 & 3.1 & 2.3 & 2.85 \\
\hline $\begin{array}{l}\text { VBR }(\mathbf{k V}) \\
\text { DATASHEET }\end{array}$ & $\begin{array}{c}\text { IEC } \\
60156\end{array}$ & & & & \\
\hline $\begin{array}{l}\text { - Before } \\
\text { treatment }\end{array}$ & & $>45$ & $>30$ & $40-60$ & \\
\hline - After & & $>75$ & $>75$ & $>70$ & \\
\hline $\begin{array}{l}\text { MEASURED } \\
\text { - AC samples } \\
\text { - DC samples }\end{array}$ & & $\begin{array}{l}87 \\
87\end{array}$ & $\begin{array}{l}82 \\
82\end{array}$ & $\begin{array}{l}84 \\
80\end{array}$ & \\
\hline $\begin{array}{l}\text { Dielectric } \\
\text { strength } \\
(\mathbf{k V} / \mathbf{m m})\end{array}$ & $\begin{array}{l}\text { ASTM } \\
\text { D149 }\end{array}$ & I & I & 1 & 15 \\
\hline $\begin{array}{l}\text { Water content } \\
(\mathrm{mg} / \mathrm{kg})\end{array}$ & $\begin{array}{l}\text { IEC } \\
60814\end{array}$ & & & & \\
\hline $\begin{array}{l}\text { DATASHEET } \\
\text { MEASURED }\end{array}$ & & $\begin{array}{c}50 \\
\text { Typical }\end{array}$ & $\begin{array}{c}50 \\
\text { Typical }\end{array}$ & $\begin{array}{l}<20 \\
\text { typical }\end{array}$ & \\
\hline $\begin{array}{l}\text { - AC samples } \\
\text { - DC samples }\end{array}$ & & $\begin{array}{l}111 \\
127\end{array}$ & $\begin{array}{l}242 \\
261\end{array}$ & $\begin{array}{c}11 \\
9\end{array}$ & \\
\hline
\end{tabular}

\section{B. Substrate Preparation}

For this study, we worked on an AlN ceramic substrate Fig. 2 , its dimensions were $40 \times 40 \mathrm{~mm}$ and $1 \mathrm{~mm}$ thickness. For technology reasons, copper tape circular electrodes were chosen. Several electrodes areas and gaps were tested. With 50 $\mathrm{mm}$ electrode diameter the VBR is higher than the others. On the other hand, there is no difference of the VBR between 10 and $14 \mathrm{~mm}$ diameter in synthetic ester oil TABLE II. So, for the implementation we used a $14 \mathrm{~mm}$ diameter, $0.165 \mathrm{~mm}$ thick copper discs with $0.127 \mathrm{~mm}$ thick acrylic tape (conductor).

TABLE II. INFLUENCE OF THE ELECTRODE DIAMETER ON BREAKDOWN VOLTAGE LEVEL

\begin{tabular}{cccccc}
\hline $\begin{array}{c}\text { Electrode } \\
\text { diameter } \\
(\mathbf{m m})\end{array}$ & $\mathbf{1 0}$ & $\mathbf{1 4}$ & $\mathbf{5 0}$ & $\begin{array}{c}\text { Difference } \\
\text { between } \mathbf{1 0} \\
\text { and } \mathbf{1 4} \mathbf{~ m m} \\
\mathbf{( \% )}\end{array}$ & $\begin{array}{c}\text { Difference } \\
\text { between 10 } \\
\text { and } \mathbf{5 0} \mathbf{~ m m} \\
\mathbf{( \% )}\end{array}$ \\
\hline $\begin{array}{c}\text { VBR (kV) } \\
\text { GAP 2 } \mathbf{~ m m}\end{array}$ & 15.4 & 15.1 & 19.5 & 2.1 & 20.8 \\
\hline $\begin{array}{c}\text { VBR (kV) } \\
\text { GAP 4 mm }\end{array}$ & 16.7 & 16.7 & 20.5 & 0.2 & 18.7 \\
\hline
\end{tabular}

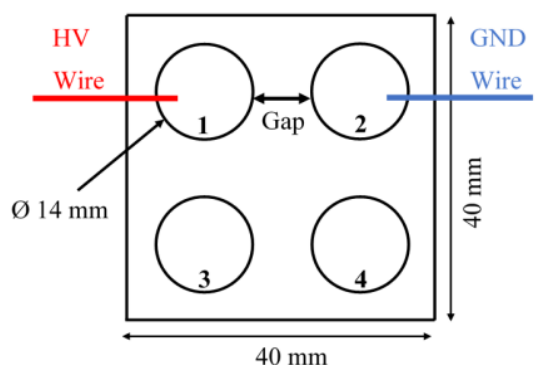

Fig. 2. Up view of the tested substrate.

Concerning the gaps, we performed measurements with 1 $\mathrm{mm}, 5 \mathrm{~mm}$ and $10 \mathrm{~mm}$. Afterwards, tinned and annealed cooper connections were soldered on the electrodes, the wire section was $0.8 \mathrm{~mm}^{2}$. Finally, the substrate is set down inside a polystyrene cell and then filled by the encapsulant (Fig3). We performed 5 breakdowns for each couple of electrodes i.e. between the electrodes 1 and 2, 5 trials were carried out, then for the electrodes 1 and 3 , and so on. In the following, a "test sample" means a couple of electrodes. This configuration allows to increase the number of test by substrate. One-minute interval between each trial.

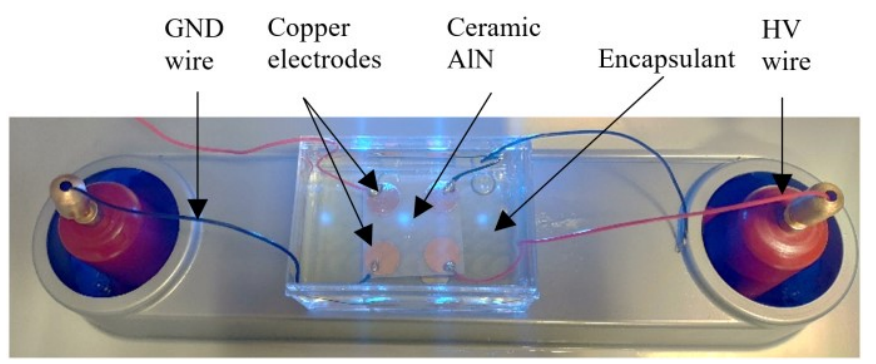

Fig. 3. View of the tested substrate embedded in a liquid encapsulant.

\section{AC/DC Breakdown Tests Setup}

The breakdown voltage measurements were made with the BAUR DTA $100 \mathrm{C}$ oil tester. It provides a voltage up to 100 $\mathrm{kV}_{\mathrm{RMS}}$, with a setting slew-rate of $0.5-10 \mathrm{kV} / \mathrm{s}$, according to the IEC 60156. The tests were performed at AC $50 \mathrm{~Hz}, 2 \pm 0.2$ $\mathrm{kV} / \mathrm{s}$.

For DC tests, a DC Spellman power supply $(+200 \mathrm{kV}, 2$ $\mathrm{mA}$ ) was used. The slew-rate voltage was $2 \mathrm{kV} / \mathrm{s}$. A HV resistive divider with a ratio of 1:100000 and a voltmeter with an accuracy of $\pm 3.5 \%$ were used to the voltage measurements.

All the experiments were done in normal pressure and at room temperature 12 to $18^{\circ} \mathrm{C}$.

\section{MEASUREMENT RESULTS AND DisCUSSIONS}

\section{A. AC Breakdown Voltage at Various Gaps}

TABLE III. indicates the number of tests samples. We performed 5 breakdowns for each test sample. Fig. 4 gives the mean value obtained for each first AC breakdown voltage. VBR was measured for the four encapsulants and for 3 gaps. 
Fig. 5 (resp. Fig. 6) represents the mean VBR for the 5 successive breakdowns for $1 \mathrm{~mm}$ gap (resp. $10 \mathrm{~mm}$ ). The results for a $5 \mathrm{~mm}$ gap are similar thus are not depicted.

The breakdown voltage increases with the gap (Fig. 4). For each gaps, there is no significant material dependence.

For the silicone gel, the breakdown voltage decreases drastically after the first test (Fig. 5 \& Fig. 6). Looking at the test samples we can observe traces in the gel meaning that the breakdown is localized in the gel volume.

In contrast, breakdown voltage drops slightly until the fifth test with oils. This behavior highlights the self-healing well-known in oils [9] [10]. However, we noticed some surface traces on the substrate after the fifth test coming from eventually the beginning of a surface discharge.

TABLE III. NUMBER OF SAMPLES TESTED IN $50 \mathrm{~Hz}$ AC BY ENCAPSULANT AND GAP

\begin{tabular}{ccccc}
\hline $\begin{array}{c}\text { GAP } \\
(\mathbf{m m})\end{array}$ & $\begin{array}{c}\text { Synthetic } \\
\text { ester }\end{array}$ & $\begin{array}{c}\text { Natural } \\
\text { ester }\end{array}$ & $\begin{array}{c}\text { Mineral } \\
\text { oil }\end{array}$ & $\begin{array}{c}\text { Silicone } \\
\text { Gel }\end{array}$ \\
\hline $\mathbf{1}$ & 4 & 4 & 4 & 8 \\
\hline $\mathbf{5}$ & 4 & 4 & 4 & 4 \\
\hline $\mathbf{1 0}$ & 4 & 3 & 3 & 4 \\
\hline
\end{tabular}

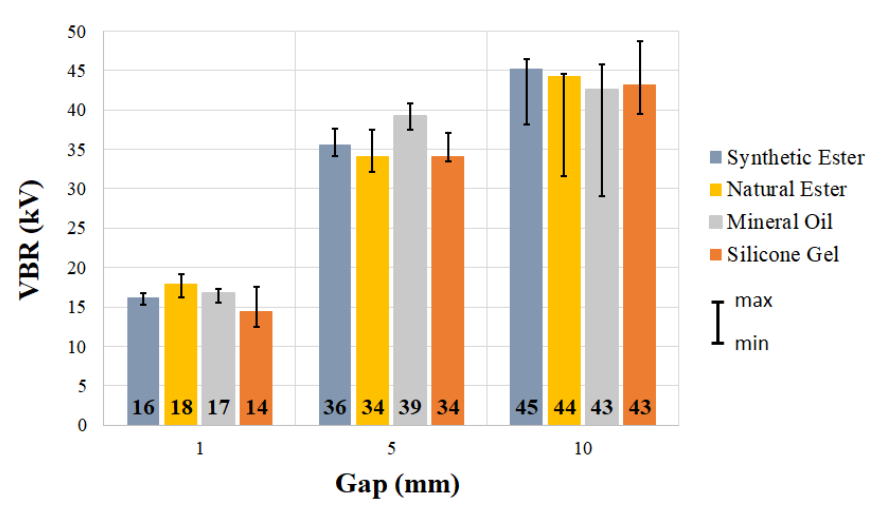

Fig. 4. Average breakdown voltage of different encapsulants in function of gap - AC $50 \mathrm{~Hz}$ voltage.

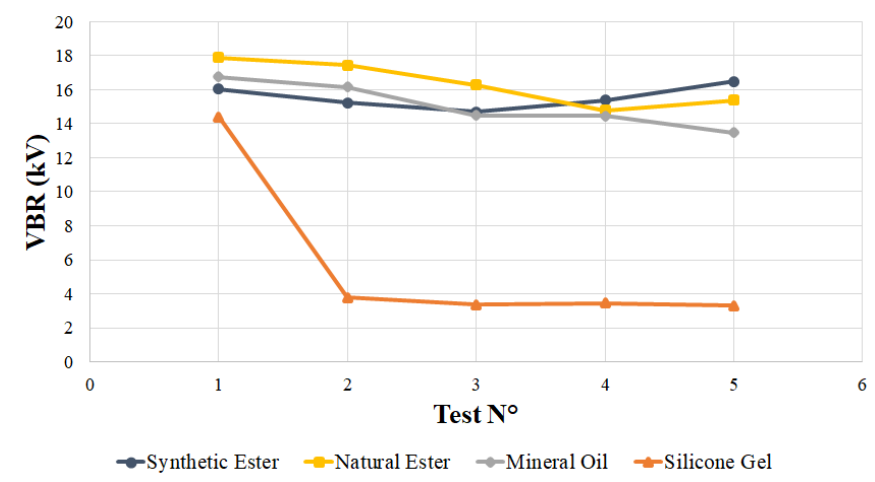

Fig. 5. AC Breakdown voltage comparison of different encapsulants, gap 1 $\mathrm{mm}$

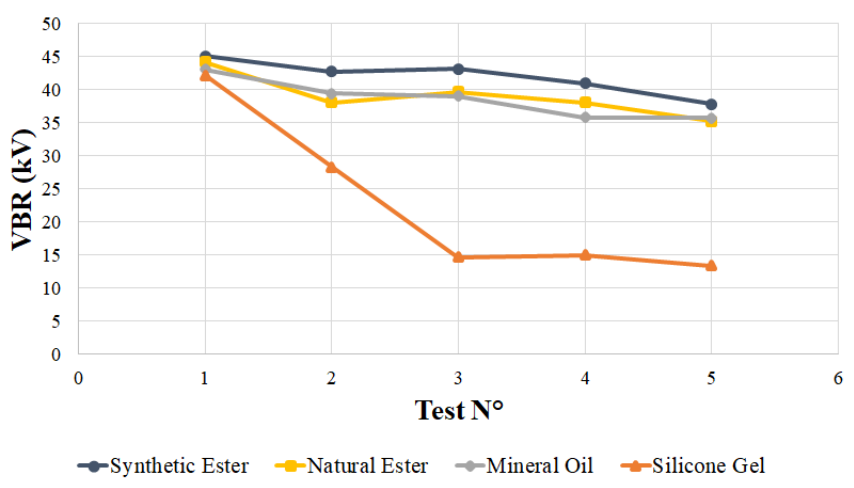

Fig. 6. AC Breakdown voltage comparison of different encapsulants, gap 10 $\mathrm{mm}$

\section{B. DC Breakdown Voltage at various Gaps}

The same series of measurements as AC were carried out with DC voltage and the results are summarized and depicted in the TABLE IV. Fig. 7 - Fig. 9.

Breakdown voltage increases with the gap (Fig. 7). There is no significant difference between the 3 liquids whereas the silicone gel has a clearly higher DC breakdown voltage.

Self-healing of the oils seems to be contradicted, especially for the highest gap (Fig. 9). Looking at the test samples filled with oils we can observe a black path on the substrate between the two electrodes created by the breakdowns, even after the first test for some samples. A surface degradation of the substrate is visible. For the silicone gel the breakdown seems to be in the volume. This point will be discussed further.

TABLE IV. NUMBER OF SAMPLES TESTED IN DC BY ENCAPSULANT AND GAP

\begin{tabular}{ccccc}
\hline $\begin{array}{c}\text { GAP } \\
(\mathbf{m m})\end{array}$ & $\begin{array}{c}\text { Synthetic } \\
\text { ester }\end{array}$ & $\begin{array}{c}\text { Natural } \\
\text { ester }\end{array}$ & $\begin{array}{c}\text { Mineral } \\
\text { oil }\end{array}$ & $\begin{array}{c}\text { Silicone } \\
\text { Gel }\end{array}$ \\
\hline $\mathbf{1}$ & 4 & 3 & 4 & 3 \\
\hline $\mathbf{5}$ & 2 & 3 & 2 & 3 \\
\hline $\mathbf{1 0}$ & 2 & 3 & 2 & 3 \\
\hline
\end{tabular}

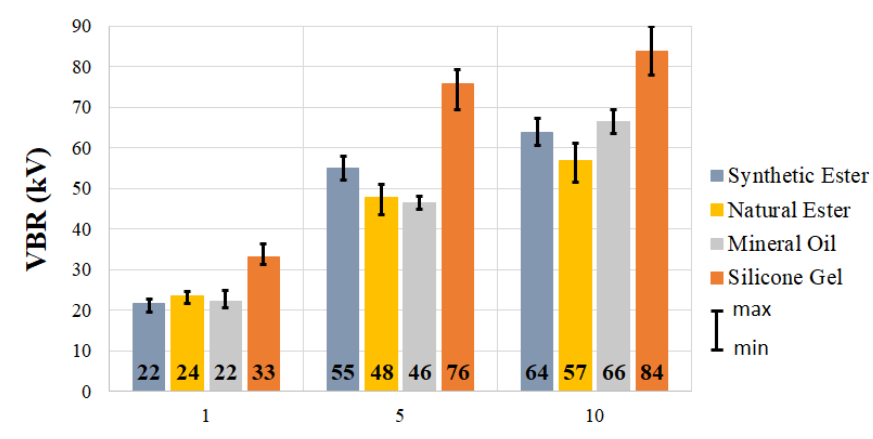

Gap (mm)

Fig. 7. Average breakdown voltage of different encapsulants in function of gap - DC voltage - 


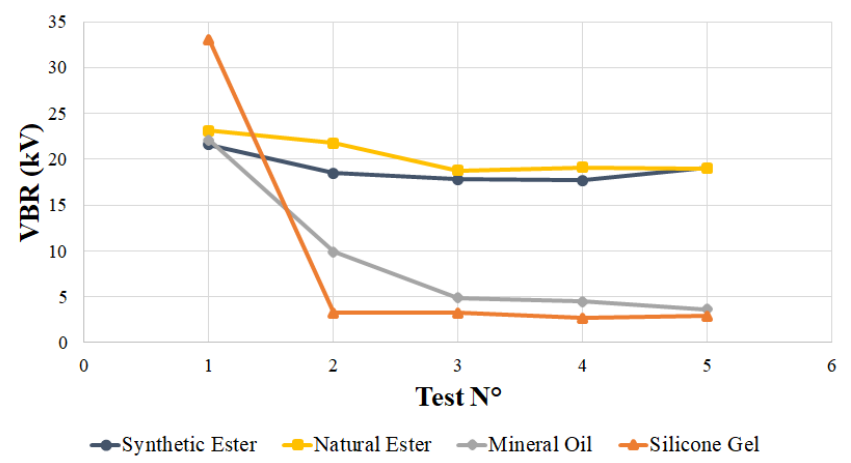

Fig. 8. DC Breakdown voltage comparison of different encapsulants, gap 1 $\mathrm{mm}$

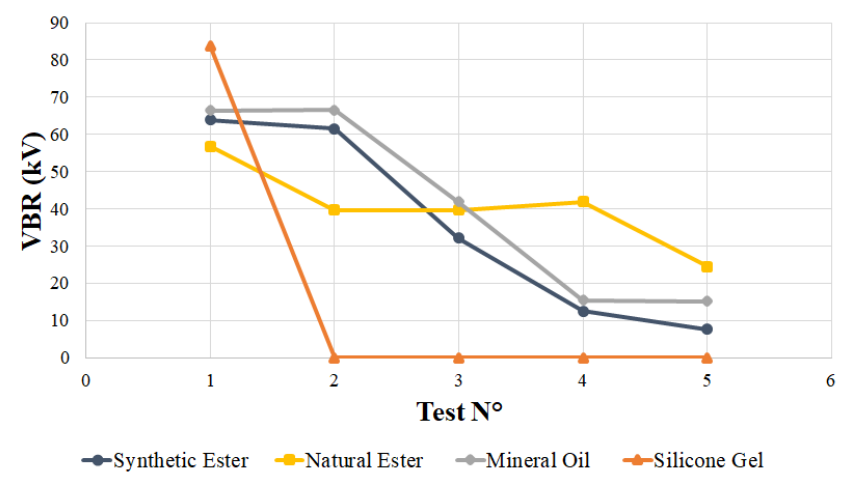

Fig. 9. DC breakdown voltage comparison of different encapsulants, gap 10 $\mathrm{mm}$

\section{Comparison of AC and DC Breakdown Voltages}

In Fig. 10 the breakdown voltages are depicted for the ester synthetic oil and the silicone gel for both AC and DC conditions and for the three gaps $(1,5,10 \mathrm{~mm})$. For the experimental test conditions chosen the breakdown voltages in DC are higher than that in AC in compliance with classical breakdown results. It is well known that the injection of charges decreases the field at the electrode due to the accumulation of homocharges. In the case of the synthetic ester oil, Beroual et al. [6] has shown that by applying the IEC 60156 standard (uniform field) on the oil alone, the $\mathrm{AC}$ breakdown voltage is higher than that at $\mathrm{DC}$. The test conditions are different in our study, maybe more similar to divergent field tests. Either way, more investigations have to be perform to assess this hypothesis.

Another point to emphasize is the different consequences of breakdown on the surface substrate for the oil samples. In DC conditions, breakdown leads to a conductive path on the surface substrate canceling the oil self-healing capability. It would seem that the energy released by DC breakdowns is higher than that in AC. This may come from the voltage sources turn-off. Indeed, in DC the manual turn-off of the source when breakdown occurs is slower than the BAUR oil tester turn-off (less than 10 microseconds).

Furthermore, when using liquid encapsulants, the breakdown sometimes occurs on the liquid/ceramic interface whatever the electrical conditions (DC or AC). For the silicone gel, the breakdowns occur in the volume, rarely at the $\mathrm{gel} /$ ceramic interface. Moreover, stronger degradation of the ceramic in the case of liquids was observed. The implementation was different compared to the silicone gel that was degassed. This difference of behavior on the degradation localization would be due to air bubbles trapped in the oilsubstrate interface which weakens the dielectric strength.

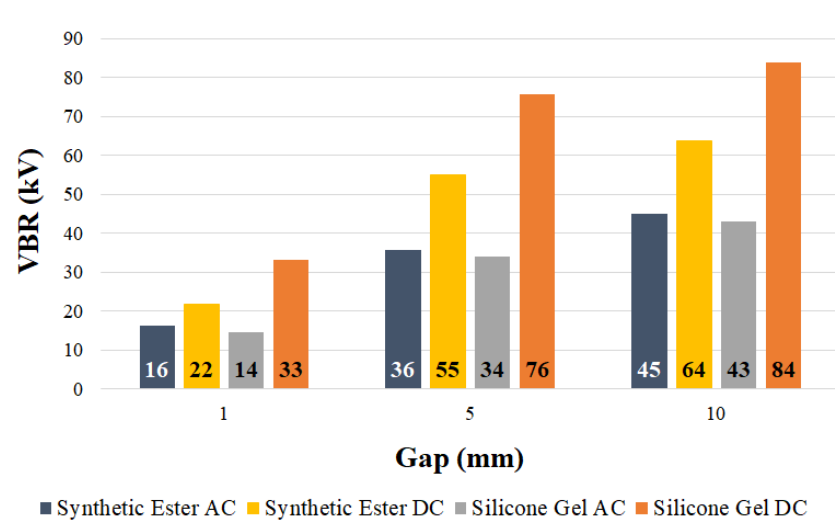

Fig. 10. AC/DC Breakdown voltage comparison of two encapsulants, synthetic ester and silicone gel

\section{CONCLUSION}

The AC breakdown voltage of the four encapsulants were quite similar with the different tested gaps. Silicone gel encapsulant has the highest voltage breakdown in DC tests comparing to the liquids.

While breakdown in the silicone gel occurs in the volume, breakdown in the oil samples damages the surface substrate. More investigations have to be performed to assess the hypothesis of air bubbles trapped at the surface substrate during the filling process. Partial discharges detection could allow to check this hypothesis. Indeed, with the presence of micro-voids the time resolved partial discharges pattern shows a specific form. The peaks of current induced by discharges appear before the maximum voltage for the both positive and negative.

The AC and DC breakdown voltage seems to not be a discriminating factor for uses in the power electronics applications. However, this have to be verified regards to the repetitive high $\mathrm{dV} / \mathrm{dt}$ voltages more representative of power electronics signals.

\section{REFERENCES}

[1] A. A. Abdelmalik, M. D. Borge, A. Nysveen, L. E. Lundgaard, and D. Linhjell, "Statistical analysis of dielectric breakdown of liquid insulated printed circuit boards," IEEE Transactions on Dielectrics and Electrical Insulation, vol. 23, no. 4, pp. 23032310, Aug. 2016.

[2] I. Fofana, "50 years in the development of insulating liquids," IEEE Electrical Insulation Magazine, vol. 29, no. 5, pp. 13-25, Sep. 2013.

[3] S. Singh, M. M. Mohsin, A. Masood, and S. Khatoon, "Advances in the field of insulating liquids used in electric power equipment and their perspectives-a review," in 2016 International Conference on Recent Advances and Innovations in Engineering (ICRAIE), 2016, pp. 1-5.

[4] I. Mudawar, "Direct-immersion cooling for high power electronic chips," in [1992 Proceedings] Intersociety Conference on Thermal Phenomena in Electronic Systems, 1992, pp. 74-84. 
[5] K. Vladimirova, J. Crebier, Y. Avenas, C. Schaeffer, and S. Litaudon, "Innovative heat removal structure for power devices - The drift region integrated microchannel cooler," in 2011 IEEE 23rd International Symposium on Power Semiconductor Devices and ICs, 2011, pp. 332-335.

[6] L. M. Boteler, M. Hinojosa, V. A. Niemann, S. M. Miner, and D. Gonzalez-Nino, "High voltage stacked diode package with integrated thermal management," in 2017 16th IEEE Intersociety Conference on Thermal and Thermomechanical Phenomena in Electronic Systems (ITherm), 2017, pp. 913-920.
[7] M. Horio, Y. Iizuka, and Y. Ikeda, "Packaging Technologies for SiC Power Modules," Fuji Electric Review, Jan. 2012.

[8] IEC 60156:1995, "Insulating liquids - Determination of the breakdown voltage at power frequency - Test method," Aug. 1995.

[9] M. S. Naidu and V. Kamaraju, High voltage engineering, 2. ed. New York: McGraw-Hill, 1996.

[10] R. Bartnikas, "Partial discharges. Their mechanism, detection and measurement," IEEE Transactions on Dielectrics and Electrical Insulation, vol. 9, no. 5, pp. 763-808, Oct. 2002. 